\title{
IMPLEMENTASI PROGRAM PREVENTION MOTHER TO CHILD TRANSMISSION (PMTCT) DI KOTA BENGKULU TAHUN 2014
}

\author{
Wisuda Andeka Marleni, Reka Lagora Marsofely, Yuniarti \\ Politeknik Kesehatan Kementerian Kesehatan Bengkulu, Jurusan Kebidanan, \\ Jalan Indragiri Nomor 03 Padang Harapan Kota Bengkulu \\ jmkbengkulu@yahoo.com
}

\begin{abstract}
Human Immunideficiency Virus (HIV) can be transmitted through a variety of ways, one is through transmission from the mother to her unborn child / mother to child transmission (MTCT). According to the risk factors, the spread of AIDS in Indonesia JanuaryJune 2012 was dominated by heterosexuals $82.6 \%, 6.6 \%$ of injecting drug users, MSM as much as $3.6 \%$, and $4.2 \%$ mother to child. The purpose of this research is to examine how the implementation of the program for prevention of HIV / AIDS from mother to baby or Prevention of Mother to Child Transmission (PMTCT) in the city of Bengkulu. This research uses the description exploratory study with a qualitative approach, conducted at the VCT clinic Hospital Dr. M.Yunus Bengkulu. Subject or primary informants in this research are pregnant women with HIV acquired the snowball technique and secondary informant as triangulation is the executive officer in the VCT clinic. The analysis showed the limited number of human resources for PMTCT program in RS M Yunus so it still takes energy counselors and activity funds for promotive not been allocated, in addition to the activities they lead to VCT yet to PMTCT and socialization PMTCT is still within the scope of an individual when pregnant women PLWHA consul in VCT and not run when the ANC in other health care (17 $\mathrm{T}$ is not already running). Based on this is expected to improve the quality of human resources and also implementing PMTCT programs for relevant agencies to support policies and is committed to the program and the budget allocation socialization PMTCT program to health centers in the province of Bengkulu.
\end{abstract}

Keywords : implementation, PMTCT Program

\begin{abstract}
Abstrak : Human Immunideficiency Virus (HIV) bisa ditularkan melalui berbagai cara, salah satunya adalah melalui penularan dari ibu kepada bayi yang dikandungnya/mother to child transmission (MTCT). Menurut faktor risiko, penyebaran AIDS di Indonesia Januari-Juni 2012 didominasi oleh heteroseksual 82,6\%, penasun 6,6\%, LSL sebanyak 3,6\%, dan ibu ke anak $4,2 \%$. Penelitian ini bertujuan untuk mengkaji bagaimana pelaksanaan program pencegahan penularan HIV/AIDS dari ibu ke bayi atau Prevention Mother to Child Transmision (PMTCT) di kota Bengkulu. Penelitian ini menggunakan studi deskripsi exploratory dengan pendekatan kualitatif, yang dilakukan di klinik VCT RSUD Dr. M.Yunus Bengkulu. Subjek atau informan primer dalam penelitian ini adalah ibu hamil dengan HIV yang diperoleh dengan teknik snowball dan informan sekunder sebagai triangulasi yaitu petugas pelaksana di klinik VCT. Hasil analisis menunjukkan masih terbatasnya jumlah SDM untuk program PMTCT. RS M Yunus sehingga masih dibutuhkan tenaga konselor dan dana kegiatan untuk upaya promotif belum dialokasikan, selain itu kegiatan masih mengarah ke VCT belum ke PMTCT dan Sosialisasi PMTCT masih dalam lingkup individu ketika ibu hamil ODHA konsul di VCT dan belum berjalan saat ANC di pelayanan kesehatan lain (17 T belum berjalan). Berdasarkan hal tersebut diharapkan untuk peningkatan kualitas SDM pelaksana program PMTCT dan juga bagi instansi terkait untuk dukungan kebijakan dan komitmen tinggi dalam alokasi anggaran program ini serta sosialisasi program PMTCT ke wilayah kerja Puskesmas-puskesmas di Provinsi Bengkulu.
\end{abstract}

Kata kunci : implementasi, Program PMTCT

Penyakit Acquired Immunity Deficiency Syndrome (AIDS) yang diakibatkan oleh Human
Immuno Deficiensy Virus (HIV), dianggap oleh seluruh lapisan masyarakat dunia sebagai 
suatu malapetaka global. Penyebaran HIV terus berlangsung dan ini merupakan masalah serius terhadap kesehatan masyarakat. Kementerian Kesehatan memperkirakan Indonesia sebagai salah satu negara epidemi yang paling cepat berkembang. Jumlah kumulatif kasus HIV dari tahun 2005 hingga Juni 2012 adalah 86.762 kasus dan jumlah kasus HIV pada Januari-Juni 2012 adalah 9.883 kasus. Sedangkan jumlah kumulatif kasus AIDS dari tahun 1987 sampai dengan Juni 2012 sebanyak 32.103 kasus. Menurut jenis kelamin kasus HIV di Indonesia pada Januari-Juni 2012 lakilaki masih mendominasi yaitu 5636 kasus $(57,0 \%)$ dan perempuan 4.244 kasus $(43 \%)$.

Human Immunideficiency Virus (HIV) bisa ditularkan melalui berbagai cara. Di Indonesia, faktor penularan HIV terbesar adalah penularan melalui hubungan seksual tanpa kondom ataupun penggunan jarum suntik tidak steril dikalangan pengguna narkoba. Salah satu faktor penularan lainnya adalah melalui jalur penularan dari ibu kepada bayi yang dikandungnya/mother to child transmission (MTCT).Menurut faktor risiko, penyebaran AIDS di Indonesia Januari-Juni 2012 didominasi oleh heteroseksual 82,6\%, penasun $6,6 \%$, LSL sebanyak $3,6 \%$, dan ibu ke anak $4,2 \%$.

Di Indonesia terdapat 4,5 juta kehamilan setiap tahunnya, diperkirakan sekitar $25 \%$ beresiko menimbulkan penularan HIV dari ibu ke bayi. Salah satu program penanggulangan HIV yang tertuang di dalam STRANAS 20102014 adalah Prevention Mother To Child Transmition (PMTCT) tidak hanya untuk ibu pengidap HIV/AIDSpositif. PMTCT dijalankan sebagai program prioritas.

Di negara maju, tingkat penularan infeksi HIV dari ibu dengan HIV positif yang hamil kepada bayinya telah turun hingga kurang dari $2 \%$ berkat penerapan terapi antiretroviral (ARV) yang mampu mencegah penularan vertikal yang disertai dengan kelahiran melalui operasi Caesar dan pemberian susu pengganti kepada si bayi sejak lahir. Namun secara global cakupan layanan PMTCT masih rendah (kira-kira baru $21 \%$ dari perkiraan jumlah ibu HIV positif yang hamil di seluruh dunia yang seharusnya memperoleh pelayanan PMTCT), termasuk di Indonesia. Hal tersebut disebabkan karena mereka tidak mengetahui status HIV-nya, atau tidak adanya fasilitas pelayanan PMTCT di tempat ODHA tersebut.

Konsep dasar PMTCT adalah menurunkan Viral load serendah-rendahnya, meminimalkan paparan janin/bayi dari cairan tubuh HIV positif, lalu mengoptimalkan kesehatan bayi dari ibu dengan HIV positif. Strategi yang dilakukan dalam kegiatan PMTCT (Prevention Mother To Child Transmision) adalah sebagai berikut (1) Mencegah terjadinya penularan HIV pada perempuan usia reproduksi, (2) Mencegah kehamilan yang tidak direncanakan pada ibu HIV positif, (3) Mencegah terjadinya penularan HIV dari Ibu hamil HIV positif ke bayi yang dikandungnya, (4) Memberikan dukungan psikologis, sosial dan perawatan kepada ibu HIV positif beserta bayi dan Keluarganya.

Walaupun berbagai upaya telah dilaksanakan selama beberapa tahun, ternyata cakupan PMTCT masih rendah yaitu $10 \%$ di tahun 2004, kemudian meningkat menjadi $35 \%$ pada tahun 2007 dan $45 \%$ di tahun 2008 sesuai dengan laporan Universal Akses 2009. Bahkan pada laporan Universal Akses 2010, cakupan layanan PMTCT di Indonesia masih sangat rendah, yaitu sebesar $6 \%$, sehingga upaya peningkatan cakupan sejalan dengan program pencegahan perlu ditingkatkan.

Angka prevalensi infeksi AIDS di Provinsi Bengkulu setiap tahun jumlahnya meningkat. Penularan HIV/AIDS di Bengkulu cukup mengkhawatirkan jika dilihat data dari tahun 2008 hingga 2012. Pada tahun 2008 terdapat 172 kasus, tahun 2009 terdapat 245 kasus, tahun 2010 terdapat 293 kasus, tahun 2011 terdapat 322 kasus serta di tahun 2012 sejumlah 334 kasus, 75\% diantaranya tertular melalui seks bebas baik dengan wanita penjaja seks (WPS) maupun sesama jenis.

Kegiatan PMTCT tersebut awalnya dilakukan di klinik VCT karena pasien yang datang merupakan hasil penjangkauan dari LSM dan VCT mobile. Pada tahun 2012, 4 orang ODHA perempuan yang mengikuti program PMTCT, 3 diantaranya sudah bersalin ditolong secara caesar dan 1 orang lagi 
dalam proses pengawasan tim PMTCT sedang hamil 4 bulan. Namun tidak itu saja Tim PMTCT telah menjaring 4 orang ibu hamil yang dicurigai dari hasil anamnesa negatif. 2 orang bayi lahir berasal dari ibu ODHA, kehamilan yang tak direncanakan dalam program PMTCT yang pada saat akan melahirkan saja datang ke rumah sakit. Di tahun 2011 yang lalu terdapat 2 orang ibu bersalin HIV postif melahirkan di ruang VK seteleh dittolong persalinan 2 minggu baru terdeteksi ibu tersebut dengan HIV karena suami di rawat VCT, sampai saat ini status HIV/AIDS bayi tersebut belum diketahui. Adanya ketidaksiapan penanganan kasus dan kurangnya penjangkauan.

Standarnya, seluruh Ibu hamil yang melakukan pemeriksaan kehamilan (ANC) pada fasilitas kesehatan harus mendapat pelayanan dengan standard 17T, yang salah satu nya adalah konseling mengenai HIV/AIDS untuk diketahui faktor risiko sehingga dapat dilakukan konseling dan tes HIV sebagai skrining awal. Namun karena adanya keterbatasan sumber daya manusia yang profesional sebagai konselor, pasien PMTCT merupakan rujukan dari Klinik VCT. Sehingga kegiatan prong 1 dan prong 2 belum optimal terlaksana. Fokus kegiatan program PMTCT pada prong 3 dan prong 4, pasien tidak mengetahui status HIV nya sudah hamil dan persiapan persalinan baru mendatangi Rumah Sakit sehingga pengawasan kurang dan berisiko pada anak yang dilahirkan untuk tertular HIV/AIDS. Adanya ketidaksiapan dalam menghadapi pasien dan kurang adanya penjangkauan terhadap ibu hamil dengan HIV/AIDS.

RSUD DR M Yunus merupakan pusat rujukan dari 18 rumah sakit yang ada di Provinsi Bengkulu. Program PMTCT di RSUD DR. M. Yunus Provinsi Bengkulu resmi berjalan pada tahun 2011 dengan dikeluarkannya Surat Keputusan Direktur RSUD DR M Yunus Bengkulu. Tim PMTCT beranggotakan 5 provider yang terdiri dari dokter spesialis kandungan, dokter anak dan bidan. Saat ini Puskesmas Penurunan menjadi salah satu Puskesmas percontohan bagi Puskesmas lain yang seyogyanya mampu men- jalankan program PMTCT terutama dalam rangka screening awal sehingga dapat menjangkau ibu-ibu hamil dengan HIV/AIDS. Namun sejauh ini belum bisa terlihat bentuk pelaksanaan berjalannya program PMTCT di kota Bengkulu.

Jumlah populasi ibu hamil yang ada di Bengkulu sejumlah 40.910, dibutuhkannya langkah nyata, komitmen serta regulasi bagi penanganan HIV/AIDS. Kurang sensitifnya program pada perempuan dan anak semakin diperjelas dengan alokasi anggaran yang disediakan oleh pemerintah. Selama ini sumber dana PMTCT berasal dari bantuan lembaga asing. Sumber dana dalam negeri ataupun pemerintah daerah masih sangat kecil. Tujuan penelitian ini adalah untuk mengetahui pelaksanaan kegiatan program pencegahan penularan HIV/AIDS dari ibu ke bayi (PMTCT) di kota Bengkulu.

\section{BAHAN DAN CARA KERJA}

Penelitian ini menggunakan studi deskripsi exploratory dengan pendekatan kualitatif. Populasi dalam penelitian ini adalah seluruh ibu bersalin yang ada di buku register ibu bersalin Ruang CI Kebidanan RSUD M.Yunus Bengkulu Tahun 2012 pada sebanyak 1060 orang. Sampel penelitian ini adalah ibu bersalin di RSUD Dr. M Yunus Bengkulu sebanyak 290 orang diambil secara purposive sampling. Teknik pengumpulan data dengan menggunakan data sekunder dengan cara melihat catatan medik di lembar register ibu bersalin dengan diagnosis kala II lama di ruang C1 kebidanan RSUD M Yunus. Analisis data menggunakan uji chi-kuadrat.

\section{HASIL}

Tabel 1. Karakteristik Informan Penelitian

\begin{tabular}{|c|c|c|c|c|c|}
\hline Kode & Umur & Asal & $\begin{array}{l}\text { Pendi- } \\
\text { dikan }\end{array}$ & $\begin{array}{c}\text { Peker- } \\
\text { jaan }\end{array}$ & Status \\
\hline Es & 29 th & $\begin{array}{c}\text { Arga } \\
\text { makmur }\end{array}$ & SMA & IRT & $\begin{array}{l}\text { ODHA hamil } \\
\text { anak pertama, } \\
\text { suami negatif. }\end{array}$ \\
\hline F & 25 th & Curup & SMP & IRT & $\begin{array}{l}\text { ODHA hamil } \\
\text { anak pertama, } \\
\text { suami positif. }\end{array}$ \\
\hline Ay & 32 th & Bengkulu & $\begin{array}{c}\text { DIII } \\
\text { Akuntansi }\end{array}$ & IRT & $\begin{array}{l}\text { ODHA hamil } \\
\text { anak kedua, } \\
\text { suami positif. }\end{array}$ \\
\hline
\end{tabular}


Tabel 2. Karakteristik Informan Sekunder

\begin{tabular}{|c|c|c|c|c|}
\hline Kode & Umur & $\begin{array}{c}\text { Jenis } \\
\text { Kelamin } \\
\end{array}$ & Pendidikan & Jabatan \\
\hline T1 & 58 th & Perempuan & $\begin{array}{c}\text { DIII } \\
\text { Fisioterapi }\end{array}$ & $\begin{array}{c}\text { Manager } \\
\text { kasus } \\
\text { VCT. }\end{array}$ \\
\hline $\mathrm{T} 2$ & 28 th & Perempuan & SMA & $\begin{array}{c}\text { Out } \\
\text { Reach }\end{array}$ \\
\hline
\end{tabular}

\section{Pelaksanaan PMTCT}

Hasil penelitian diketahui bahwa kegiatan PMTCT di RSUD Dr M Yunus Bengkulu belum berjalan secara optimal karena tim PMTCT lebih banyak melakukan program yang mengarah kepada pelayanan yang berada di Prong 3 dan Prong 4. Sehingga, ibu hamil dengan HIV baru diketahui statusnya pada saat sudah hamil atau saat akan melakukan persalinan. Pelaksanaan kegiatan PMTCT di RSUD DR M Yunus Bengkulu belum maksimal karena kegiatan program PMTCT masih tergabung dan dipegang oleh tim VCT, seperti kutipan berikut :

“...Belum pernah tau samo sekali, pas hamil dan tau HIV tula langsung di kasih tau ikut program...” (Ay)

“...Kegiatan yang baru kita lakukan, kalo ada ODHA yang hamil, kita masukan program, kita kontrol, arv, periksa hamilnya,yang terpenting pada saat persiapan persalinan karena banyak yang terlibat kan melahirkannya harus SC..."(T1)

\section{Sumber Daya Manusia (SDM)}

Hasil penelitian menunjukkan bahwa masih terbatasnya sumber daya di klinik VCT khususnya bagian MTCT. Salah satu Manager Kasus mengungkapkan bahwa tanggung jawab yang mereka emban merangkap di beberapa tugas misalnya Manager kasus merangkap konselor. Bahkan ada juga penjangkau lapangan merangkap bagian administrasi. Seperti ungkapan berikut :

“...aih kalau kami ini mba semua dikerjakan, merangkap, ya lapangan ya adm,,malah bude tu MK iya, konselor iya, masih kurang mba...”(T2)

Hasil wawancara yang dilakukan dengan konselor, RSUD DR M Yunus Bengkulu memiliki 8 orang tenaga konselor namun dikarenakan kesibukan dan mutasi banyak konselor yang tidak dapat bertugas sebagaimana mestinya saat ini hanya 3 orang konselor yang aktif dalam memberikan pelayanan.

\section{Dana}

Kendala yang dihadapi oleh tim PMTCT seperti yang diutarakan oleh informan sekunder alokasi dana kegiatan PMTCT di RSUD DR M Yunus Bengkulu bersumber dari bantuan Global Fund yang digunakan untuk pembelian bahan habis pakai operasi dan penanganan kasus, sementara untuk insentif mendapat bantuan dari Dinas Kesehatan. Dana kegiatan untuk upaya promotif seperti sosialisasi tidak ada.

“...dari GF, untuk klien melahirkan kira-kira untuk bahan habis pake sekitar 900rb. dan penangan kasus saja . untuk upaya promotif seperti sosialisasi itu belum ada dananya..." (T1)

\section{Kegiatan}

Hasil penelitian diketahui bahwa beberapa kegiatan yang ada pada program PMTCT di RS M Yunus Bengkulu hanya meliputi Prong 3 dan Prong 4. Rangkaian kegiatan lain terkait dengan program HIV/AIDS yang dilakukan oleh tim VCT adalah penjangkauan di lapangan. Keterbatasan jumlah tenaga, sarana dan dana memicu rangkaian program PMTCT yang seharusnya dilakukan mulai dari Prong 1 hingga prong 4 tidak terlaksana sebagaimana mestinya. Kegiatan yang dijalankan terpaku pada kebijakan sehingga tim VCT hanya mengikuti kegiatan sesuai kebijakan nasional yang ada dikarenakan dianggap adanya perbedaan pola fikir dan karakteristik masyarakat tiap daerah berbeda.

\section{Sosialisasi}

Seluruh informan menyatakan program khusus untuk sosialisasi HIV/AIDS di RSUD M Yunus Bengkulu dilakukan oleh petugas dari Forum Promosi Rumah Sakit. Sosialisasi dilaksanakan bila ada kegiatan perayaan atau acara tertentu saja dan sebatas internal Rumah Sakit. Klien menda-patkan informasi mengenai PMTCT dari sesama ODHA perempuan yang tergabung dalam pertemuan arisan yang dilakukan oleh pihak VCT ataupun di LSM. Berikut pernya-taan :

\footnotetext{
“...Sosialisasinya ga jalan,, aja kalo ada moment tertentu kayak peringatan hari AIDS sedunia ato yang lain baru jalan...” $(F)$
} 
“...kalo ada acara kumpul-kumpul, kami langsung dapat info-info baru atau jadwal rutin tiap bulan pas kumpul...”(Es)

Hasil wawancara crosscheck yang dilakukan kepada informan sekunder bahwa selama ini belum dilaksanakannya sosialisasi PMTCT pada ibu hamil. Namun untuk tenaga kesehatannya bidan dan perawat sudah di berikan penyuluhan serta sebagian bidan dari beberapa Puskesmas yang ada sudah dilatih dan nantinya secara bertahap akan diundang kembali untuk sosialisasi PMTCT dan Konselor HIV/AIDS. Berikut pernyataannya :

“...sosialisasi secara umum belum ada mengenai program PMTCT, tapi kita sudah beri sosialisasi ke nakes, tidak seluruh tapi sebagian saja pada awal tahun bulan februari 2013 lalu sempat kita berikan di hotel splash, nantinya secara bertahap akan kita latih sетиа...” (T1)

\section{PEMBAHASAN}

Dalam pelaksanaan program PMTCT, terdapat strategi pelaksanaan yang dibagi ke dalam empat prong. Terdapat 4 (empat) prong yang perlu diupayakan untuk mencegah terjadinya penularan HIV dari ibu ke bayi yaitu Pencegahan penularan HIV pada perempuan usia reproduksi; Pencegahan kehamilan yang tidak direncanakan pada ibu HIV positif; Pencegahan penularan HIV dari ibu hamil HIV positif ke bayi yang dikandungnya; Pemberian dukungan psikologis, sosial dan perawatan kepada ibu HIV positif beserta bayi dan keluarganya (Kemenkes RI, 2012).

Program PMTCT di RSUD Dr M Yunus Bengkulu merupakan kegiatan pelayanan satu atap/paket, RSUD M Yunus Bengkulu merupakan Rumah Sakit Rujukan ODHA dari 18 Rumah Sakit yang ada di Provinsi Bengkulu, berdasarkan Instruksi dari Kementrian Kesehatan RI yang di teruskan pada Dinas Kesehatan Provinsi Bengkulu untuk melakukan Kegiatan Program PMTCT (Prevention Mother To Child Transmission) sebagai tugas dan kewajiban Rumah sakit untuk melakukannya maka pada tanggal 27 Oktober 2011, di tetapkan surat keputusan No SK 821.22/HK/-RS/2011 pembentukan tim
PMTCT RSUD DR M Yunus Bengkulu untuk menunjang kelancaran dalam memberikan pelayanan kesehatan terhadap masyarakat terutama pada ibu dan bayi penderita HIV/AIDS.

Namun untuk mendukung agar program ini berjalan dengan baik dibutuhkannya banyak bagian yang terlibat salah satunya adalah kegiatan penjangkauan pada klien untuk dapat mengikuti program PMTCT. Idealnya kegiatan PMTCT terintegrasi dengan paket pelayanan KIA (Kesehatan Ibu dan Anak) namun pada kenyatannya banyak hambatan tidak berjalan sebagaimana mestinya salah satunya pada proses penjangkauan klien yang dilakukan oleh RSUD Dr M Yunus Bengkulu.

Kebijakan biasanya berkaitan erat dengan pengambil keputusan (decision maker) atau stakeholder. Bila stakeholder menganggap PMTCT adalah hal yang penting dalam upaya pencegahan penyakit HIV/AIDS maka pelayanan PMTCT akan berjalan dengan baik, karena stakeholder akan mengeluarkan kebijakan yang berkaitan dengan keputusan pemberian dana kelangsungan PMTCT. Agar pelaksanaan konseling dan testing HIV/AIDS sukarela dapat dipertanggung jawabkan secara komprehensif maka perlu adanya suatu Pedoman Pelayanan Konseling dan Testing HIV/AIDS secara sukarela yang ditetapkan dengan Keputusan Menteri Kesehatan Nomor 1507/MENKES/SK/X/2005. Didaerah kebijakan penanggulangan HIV dan AIDS dikoordinir oleh Komisi Penanggulangan AIDS Daerah (KPAD) Provinsi/Kabupaten/Kota sebagai perpanjangan tangan dari Komisi Penanggulangan AIDS Nasional (KPAN), berupa surat keputusan ditandatangani oleh masing-masing pimpinan daerah (Kemenkes, 2005).

Kegiatan pelayanan yang diberikan masih terfokus pada saat kegiatan persalinan dan pasca persalinan, bidan mengatakan bahwa mereka tidak pernah terlibat dari awal kegiatan atau perencanaan kehamilan bagi pasangan ODHA. Idealnya kegiatan PMTCT berkesinambungan sesuai dengan stategi pelaksanaanya mulai dari prong 1 sampai 
prong 4. Keempatnya merupakan pilar pencegahan penularan HIV dari Ibu ke bayi.

Dalam Panduan Tata Laksana PMTCT tersebut telah jelas dinyatakan bahwa program PMTCT harus diimplementasikan secara komprehensif yang dimulai dari prong 1, 2, 3 dan 4. Implementasi keempat prong ini tidak bisa dilakukan secara terpisah namun seyogyanya harus berjalan bersamaan dan berkesinambungan.

Implementasi program PMTCT di RSUD DR M Yunus Bengkulu masih terpusat pada prong 3. Banyak aspek penting yang terlupakan dalam pelaksanaan program, seperti; pemberian informasi HIV pada perempuan usia reproduktif, informasi yang komprehensif terkait perencanaan kehamilan pada perempuan dengan HIV dan pasangannya, pilihan-pilihan kontrasepsi, pilihanpilihan persalinan, pemberian makanan bayi serta dukungan psikologis bagi perempuan dengan HIV, suami/pasangan dan keluarganya.

Sumberdaya dalam program PMTCT merupakan faktor penting yang dapat menentukan keberhasilan program, oleh karena itu dibutuhkan ketersediaan sumber daya yang handal dan mencukupi tidak hanya terbatas pada tenaga (SDM) saja, tetapi juga sumberdaya lainnya, termasuk finansial (dana). Dana dibutuhkan untuk pembiayaan suatu organisasi atau program.

Layanan konseling dan tes HIV sukarela atau Voluntary Counseling and Testing (VCT) merupakan salah satu komponen penting dalam upaya pencegahan penularan HIV dari ibu ke bayi. Cara untuk mengetahui status HIV seseorang adalah melalui tes darah. Prosedur pelaksanaan tes darah didahului dengan konseling sebelum dan sesudah tes, menjaga kerahasiaan serta adanya persetujuan tertulis (informed consent).

Idealnya terdapat SDM yang kompeten untuk memenuhi kebutuhan pelayanan di klinik VCT khususnya program PMTCT yaitu tenaga konselor, manager kasus, tim out reach atau penjangkau lapangan, tenaga laboratorium dan tenaga administrasi.

Beberapa kendala yang dihadapi oleh tim PMTCT seperti yang diutarakan oleh manager kasus alokasi dana kegiatan PMTCT di RSUD DR M Yunus Bengkulu bersumber dari bantuan Global Fund yang digunakan untuk pembelian bahan habis pakai operasi dan penanganan kasus, sementara insentif bantuan dari Dinas Kesehatan. Dana kegiatan untuk upaya promotif seperti sosialisasi tidak ada.

Menurut Harudin salah satu faktor yang mempengaruhi pelayanan klinik VCT termasuk PMTCT di RSUP DR. Sarditjo Yogyakarta adalah faktor manajemen, antara lain ruang konseling yang kurang menjamin konfidensialitas dan kenyamanan klien, media KIE yang belum memadai serta sarana dan prasarana masih terbatas (Harudin, 2010).

Pemanfaatan pelayanan kesehatan oleh seseorang dipengaruhi oleh banyak hal. Pemanfaatan pelayanan merupakan proses yang sangat kompleks yang melibatkan keputusan individual, sosial dan pengaruh profesional kesehatan (Kemenkes, 2005).

Idealnya sosialisasi tentang PMTCT, HIV/AIDS terintegrasi dengan layanan antenatal utamanya diberikan kepada ibu hamil ke bayinya yang dapat ditularkan melalui proses persalinan dan ASI dan harapannya setelah ibu hamil mendapat sosialisasi tersebut ibu mau melakukan tes HIV untuk mengetahui status kesehatannya (Kemenkes, 2012).

Sosialisasi harus juga di dukung dengan pendidikan dan pelatihan untuk meningkatkan pelatihan dan keterampilan karyawaan. Sosialisasi PMTCT sangat penting dan dibutuhkan untuk menggugah kesadaran masyarakat terutama ibu hamil dalam upaya pencegahan penyebaran HIV/AIDS di masyarakat dan mengurangi stigma di masyarakat.

Hal ini sejalan dengan penelitian yang telah dilakukan oleh Samaran (2012) Implementasi program penjaringan PMTCT oleh bidan di puskesmas wilayah kerja dinas kesehatan Sorong Provinsi Papua Barat, bahwa pentingnya kegiatan sosialisasi dalam proses penjaringan klien, yang di pengaruhi oleh jumlah tenaga terlatih serta sarana dan prasarana dalam menunjang kegiatan program PMTCT 


\section{KESIMPULAN}

Berdasarkan hasil penelitian Implementasi Program PMTCT di RS Dr. M. Yunus Bengkulu, maka dapat disimpulkan antara lain : masih terbatasnya jumlah SDM untuk program PMTCT. RS M Yunus masih membutuhkan tenaga konselor, Dana kegiatan untuk upaya promotif belum dialokasikan, Kegiatan masih mengarah ke VCT belum ke PMTCT dan Sosialisasi PMTCT masih dalam lingkup individu ketika ibu hamil ODHA konsul di VCT dan belum berjalan saat ANC di pelayanan kesehatan lain (17 $\mathrm{T}$ belum berjalan).

\section{DAFTAR RUJUKAN}

Adisasmito, Wiku. Sistem Kesehatan. Jakarta: PT RajaGrafindo Persada; 2010.

Amirin TM. Pokok-pokok teori sistem. Jakarta: Penerbit CV Rajawali; 2007.

Azwar, A. Pengantar Administrasi Kesehatan, Edisi Ketiga, Binarupa Aksara, Jakarta 2010

Bungin B. Penelitian Kualitatif, Komunikasi, Ekonomi, Kebijakan Publik, dan Ilmu Sosial lainnya. Jakarta: Kencana Predana Media Grup; 2008.

Dinkes Provinsi Bengkulul, 2013. Profil Dinas Kesehatan Provinsi Bengkulu

Helda, N. 2010. Pemanfaatan program pencegahan penularan HIV dari Ibu ke Bayi oleh Ibu Hamil di Puskemas Hamadi Jayapura, Yogyakarta.

Kementerian Kesehatan Republik Indonesia, 2011. Pedoman pelayanan konseling dan testing HIV/AIDS secara sukarela (Voluntary Counselling and Testing). Jakarta : Direktorat Jendral Pengendalian Penyakit dan Penyehat Lingkungan.

Kementrian Kesehatan Republik Indonesia, 2008. Modul Pelatihan pencegahan HIV dari ibu ke bayi. Jakarta

Komisi Penanggulangan AIDS Nasional. Strategi nasional penanggulangan HIV dan AIDS 20102014
Rekomendasi bagi tim VCT terutama PMTCT dalam meningkatkan skill melalui pelatihan konselor dan manajer kasus serta untuk survey manajemen kasus ke daerah lain. Selain itu memperluas jaringan terutama dalam penjangkauan Ibu hamil ODHA, melakukan pendampingan pada ODHA yang ketat, melakukan pendekatan dengan keluarga ODHA. Rekomendasi juga bagi instansi terkait untuk memberikan dukungan kebijakan dan komitmen tinggi dalam alokasi anggaran untuk program PMTCT serta sosialisasi program PMTCT ke wilayah kerja Puskesmaspuskesmas di Provinsi Bengkulu.

Larsson,c. Opt-out HIV testing during antenatal care: experiences of pregnant women in rural Uganda, oktober 2010. Available from : http://heapol.oxfordjournals.org

Meyers, T. Challenges HIV Care and Treatment in South Africa. South Africa, October 2006. Available from: http://jid.oxfordjournals.org/content/196/Supple ment

Moleong LJ. 2010. Metodologi Penelitian Kualitatif, Edisi Revisi. Bandung: PT. Remaja Rosdakarya

Nasution, BR dkk. Laporan akhir Penelitian "Kualitas dan Rekomendasi Perbaikan Layanan PMTCT". Jakarta 2012

Sary, L. Analisis Kebutuhan dalam Mewujudkan Pelaksanaan Strategi Pelayanan Provider Initiated HIV Testing and Counseling (Studi Kasus di BKPM Semarang). 2009. Program Pascasarjana Promosi Kesehatan Kajian Kesehatan Reproduksi dan HIV-AIDS Undip. Semarang.

WHO, 2010, PMTCT Strategic Vision 2010-2015 "Preventing mother-to-child transmission of HIV to reach the UNGASS and Millennium Development Goal 